\title{
Characterization of the rDNA sequence of rose thrips (Thrips major Uzel) and its phylogenetic analysis
}

\author{
Poznanie sekwencji rDNA i analiza filogenetyczna wciornastka \\ cyklamenowca (Thrips major Uzel)
}

\author{
Arnika Jeszke, Żaneta Fiedler, Aleksandra Obrępalska-Stęplowska
}

\begin{abstract}
Summary
Thrips major is a polyphagous insect, which occurs on each continent. In Poland T. major usually attacks crops, ornamental plants and herbs. Although it is very common pest, there are only few fragments of its sequence available. Knowledge about its rDNA (ribosomal deoxyribonucleic acid) sequence is needed to develop new diagnostic methods that could allow for successful differentiation between T. major and other thrips species such as Frankliniella occidentalis and Thrips tabaci, which post higher risk to cultivations in Poland. The aim of this work was the characterization of rDNA sequence of $T$. major, its comparison with other thrips species' sequences followed by phylogenetic analysis. In this work new PCR (polymerase chain reaction) primers were designed which enabled rDNA fragment amplification from most of Thripinae subfamily species. PCR reaction was carried out and obtained products of amplification were sequenced, followed by bioinformatic analysis. Then, T. major 18S-ITS1-5,8S-ITS2-28S rDNA region sequences were compared with already known sequences of following thrip species: T. tabaci, T. palmi, Scirtothrips dorsalis, Echinothrips americanus, Frankliniella schulzei, F. occidentalis and F. intonsa and phylogenetic analyses were performed.
\end{abstract}

Key words: Thrips major, rose thrips, rDNA, sequencing, phylogeny

\section{Streszczenie}

Thrips major jest polifagiem występującym na wszystkich kontynentach. W Polsce bytuje zarówno na roślinach uprawnych, jak i na roślinach ozdobnych i ziołach. Pomimo powszechnego występowania, niewiele fragmentów jego genomu zostało zsekwencjonowanych. Znajomość sekwencji rDNA (ribosomal deoxyribonucleic acid - rybosomalnego kwasu deoksyrybonukleinowego) jest istotna dla opracowania diagnostyki molekularnej umożliwiającej skuteczne odróżnienie go od innych gatunków wciornastków, stanowiących większe zagrożenie dla upraw na terenie Polski, m.in. Thrips tabaci i Frankliniella occidentalis. Celem pracy było poznanie sekwencji regionu 18S-ITS1-5,8S-ITS2-28S rDNA wciornastka T. major oraz jego analiza porównawcza i filogenetyczna. W pracy zaprojektowano parę starterów uniwersalnych dla wielu gatunków z podrodziny Thripinae, umożliwiającą powielenie fragmentu rDNA T. major. Przeprowadzono reakcje PCR (polymerase chain reaction - łańcuchową reakcję polimerazy), a uzyskane w nich produkty poddano sekwencjonowaniu. Wyniki analizowano przy pomocy narzędzi bioinformatycznych. Uzyskane sekwencje T. major zestawiono z poznanymi wcześniej sekwencjami takich gatunków, jak: T. tabaci, T. palmi, Scirtothrips dorsalis, Echinothrips americanus, Frankliniella schulzei, F. occidentalis i F. intonsa oraz przeprowadzono analizy filogenetyczne.

Słowa kluczowe: Thrips major, wciornastek cyklamenowiec, rDNA, sekwencjonowanie, filogeneza

Instytut Ochrony Roślin - Państwowy Instytut Badawczy

Władysława Węgorka 20, 60-318 Poznań

a.jeszke@iorpib.poznan.pl 


\section{Wstęp / Introduction}

Wciornastki (Thysanoptera: Thripidae) są szeroko rozpowszechnione na terenie Polski i niektóre z nich (np. Thrips tabaci oraz Frankliniella occidentalis) powodują szkody w uprawach roślin o dużym znaczeniu gospodarczym. Jednym z powszechnie występujących szkodników z tego rodzaju jest Thrips major Uzel wciornastek cyklamenowiec. Owad występuje w regionie holoarktycznym (Pobożniak i Sobolewska 2011), obejmującym swoim zasięgiem całą Europę, znaczną część Azji, Amerykę Północną oraz położone na północy obszary Afryki. Wciornastek cyklamenowiec jest polifagiem o szerokim zakresie gospodarzy, w których skład wchodzą głównie rośliny ozdobne i zielne (Zawirska 1994; Pobożniak i Sobolewska 2011). Występuje także na drzewach owocowych oraz na warzywach, np. na białej kapuście (Pobożniak 2005). Częściej atakuje uprawy polowe niż szklarniowe. Żeruje głównie na liściach (Pobożniak i Sobolewska 2011). Optymalna temperatura dla rozwoju tego gatunku to $12-28^{\circ} \mathrm{C}$ (Stacey i Fellowes 2002).

Pomimo, iż występowanie wciornastka $T$. major jest powszechne, opracowania na jego temat są bardzo nieliczne, niewiele jest także zdeponowanych danych uzyskanych z sekwencjonowania DNA (kwasu deoksyrybonukleinowego) w bazach danych Banku Genów. Brak również sekwencji rDNA (rybosomalnego DNA), której znajomość jest istotna dla opracowywania metod diagnostyki molekularnej. Diagnostyka gatunkowa na podstawie cech morfologicznych jest trudna i czasochłonna, dlatego wykorzystanie technik molekularnych umożliwiających szybkie i skuteczne odróżnienie T. major od innych gatunków wciornastków, stanowiących bardzo duże zagrożenie dla upraw na terenie Polski, m.in. T. tabaci i F. occidentalis, może być szybszą oraz dokładniejszą metodą.

\section{Materiały i metody / Materials and methods}

Materiał do badań stanowiła mieszanina osobników w różnych stadiach rozwojowych populacji $T$. major pochodzącej z Torunia. Przynależność gatunkowa badanych osobników została potwierdzona morfologicznie w Centralnym Laboratorium Państwowej Inspekcji Ochrony Roślin i Nasiennictwa w Toruniu oraz w Instytucie Ochrony Roślin - Państwowym Instytucie Badawczym w Poznaniu.

\section{Izolacja DNA, projektowanie starterów i przeprowadzenie reakcji PCR (lańcuchowej reakcji polimerazy) / DNA extraction, primers design and PCR (polymerase chain reaction) analysis}

Z 3 osobników pochodzących $\mathrm{z}$ analizowanej populacji wyizolowano DNA wykorzystując zestaw DNeasy Blood $\&$ Tissue (Qiagen).

$\mathrm{Na}$ podstawie sekwencji DNA pochodzących od różnych gatunków z podrodziny Thripinae zdeponowanych w bazie NCBI (National Center of Biotechnology Information) zaprojektowano pary uniwersalnych starterów zdegenerowanych, obejmujących możliwie najdłuższy fragment 18S-ITS1-5,8S-ITS2-28S rDNA, z których do dalszych badań wykorzystano parę starterów amplifikujących fragment DNA o długości około 1900 pz (tab. 1).

Startery zostały przetestowane w reakcji PCR (polymeraze chain reaction), którą zoptymalizowano tak, aby otrzymać pojedynczy, swoisty produkt reakcji o oczekiwanej długości.

\section{Klonowanie i sekwencjonowanie produktu / Product cloning and sequencing}

Produkt amplifikacji wycięto z żelu oraz wyeluowano z wykorzystaniem zestawu Qiaex II Gel Extraction Kit (Qiagen), według procedury zalecanej przez producenta. Oczyszczony fragment DNA ligowano $\mathrm{z}$ wektorem p-GEM T-Easy (Promega), a następnie transformowano nim komórki kompetentne Escherichia coli (One Shot TOP10 Electrocompetent Cells, Invitrogen). Zrekombinowane plazmidy wyizolowano z komórek bakterii za pomocą zestawu QIAprep Spin Miniprep Kit (Qiagen) i wysłano do sekwencjonowania $\mathrm{Z}$ wykorzystaniem uniwersalnych starterów amplifikujących fragment wektora pGEM T-Easy: M13Fw i M13Rw. Do dalszych etapów wykorzystano cztery sekwencje analizowanego regionu.

\section{Analizy bioinformatyczne / Bioinformatic assays}

Uzyskane sekwencje analizowano w programie GeneDoc (Nicholas i Nicholas 1997) oraz wykonano przyrównanie wielosekwencyjne (MSA - Multiple Sequence Alignment) z wykorzystaniem sekwencji innych gatunków $\mathrm{z}$ podrodziny Thripinae, uzyskanych $\mathrm{z}$ bazy danych NCBI oraz w wyniku badań własnych (tab. 2). Przeprowadzono także analize filogenetyczną $\mathrm{z}$ wykorzystaniem programów ClustalW (Thompson i wsp. 1994) i MEGA4 (Tamura i wsp. 2007). Do konstrukcji drzewa wykorzystano algorytm Neighbor-Joining. Poziom identyczności pomiędzy sekwencjami został wyznaczony za pomocą programu BioEdit.

Tabela 1. Sekwencje starterów wykorzystanych do amplifikacji obszaru 18S-ITS1-5,8S-ITS2-28S rDNA T. major Table 1. Primers used for PCR amplification of 18S-ITS1-5,8S-ITS2-28S of rDNA region in T. major genome

\begin{tabular}{l|c|c|c}
\hline $\begin{array}{c}\text { Nazwa startera } \\
\text { Primer name }\end{array}$ & \multicolumn{1}{c|}{$\begin{array}{c}\text { Sekwencja startera } \\
\text { Primer sequence }\end{array}$} & $\begin{array}{c}\text { Temperatura przyłączania } \\
\text { Annealing temperature }\end{array}$ & $\begin{array}{c}\text { Region przyłączenia } \\
\text { Annealing region }\end{array}$ \\
\hline ThrUNI1 & CGTACAAGGTTTCCGTAGG & $54^{\circ}$ & $18 \mathrm{~S}$ rDNA \\
\hline ThrUNI3 & GTRRTCTDCCTGAACWG & & $28 \mathrm{~S}$ rDNA \\
\hline
\end{tabular}


Tabela 2. Zestawienie sekwencji wykorzystanych podczas analiz bioinformatycznych

Table 2. Sequences used in bioinformatic assays

\begin{tabular}{l|c|c}
\hline \multicolumn{1}{c|}{$\begin{array}{c}\text { Gatunek } \\
\text { Species }\end{array}$} & $\begin{array}{c}\text { Numer akcesyjny GeneBanku } \\
\text { GeneBank accession number }\end{array}$ & $\begin{array}{c}\text { Źródło } \\
\text { References }\end{array}$ \\
\hline Frankliniella occidentalis & $\begin{array}{c}\text { brak } \\
\text { no data }\end{array}$ & $\begin{array}{c}\text { badania własne (nieopublikowane) } \\
\text { own research (unpublished) }\end{array}$ \\
\hline Frankliniella intonsa & $\begin{array}{c}\text { brak } \\
\text { no data }\end{array}$ \\
\hline Frankliniella schulzei & GQ343259.1 & $\begin{array}{c}\text { badania własne (nieopublikowane) } \\
\text { own research (unpublished) }\end{array}$ \\
\hline Thrips tabaci & brak & Liu Y.C. (2004) \\
\hline Thrips palmi & no data & $\begin{array}{c}\text { badania własne (nieopublikowane) } \\
\text { own research (unpublished) }\end{array}$ \\
\hline Scirtothrips dorsalis & brak & $\begin{array}{c}\text { badania własne (nieopublikowane) } \\
\text { own research (unpublished) }\end{array}$ \\
\hline Echinothrips americanus & no data & Liu Y.C. (2004) \\
\hline
\end{tabular}

\section{Wyniki i dyskusja / Results and discussion}

W wyniku reakcji PCR ze starterami ThrUNI1/2 uzyskano produkt o pożądanej długości (rys. 1). Sekwencję DNA badanego produktu uzyskano poprzez automatyczne sekwencjonowanie, a następnie przyrównano ją do sekwencji regionu 18S-ITS1-5,8S-ITS2-28S rDNA, takich gatunków wciornastków, jak: T. tabaci, T. palmi, S. dorsalis, E. americanus, F. schulzei, F. occidentalis i $F$. intonsa.

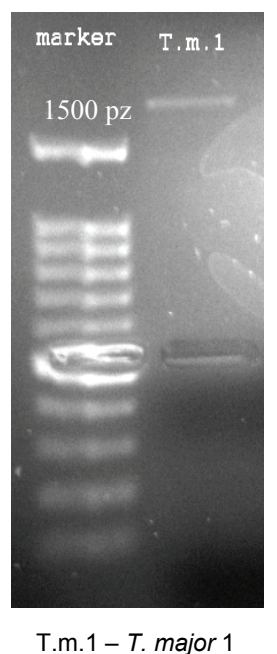

Rys. 1. Rozdział elektroforetyczny produktu reakcji PCR ze starterami ThrUNI1/2. Spodziewana długość produktu około $1900 \mathrm{pz}$

Fig. 1. Result of PCR reaction with primers ThrUNI1/2. Expected size of product $-1900 \mathrm{bp}$

Przeprowadzona analiza porównawcza sekwencji wykazała bardzo duże zróżnicowanie pomiędzy gatunkiem T. major a pozostałymi gatunkami. Poziom identyczności pomiędzy wymienionymi gatunkami wynosi zaledwie $22-30 \%$ (rys. 2). Analiza filogenetyczna wskazuje na nieco bliższe pokrewieństwo gatunku $T$. major $\mathrm{z}$ gatunkami T. tabaci i T. palmi niż z pozostałymi, jednakże dystans genetyczny pomiędzy $T$. major a innymi gatunkami jest bardzo duży (rys. 3). Pomiędzy czterema analizowanymi sekwencjami wciornastka $T$. major wykazano zróżnicowanie na poziomie $0,4-0,6 \%$.

T. major nie został do tej pory dobrze scharakteryzowany. W bazie danych NCBI zdeponowano jedynie fragment sekwencji kodowanego w mitochondriach genu COI dla tego gatunku. Nie zaproponowano także do tej pory żadnej metody diagnostyki molekularnej. Pomimo niewielkiego znaczenia gospodarczego, możliwość jego wykrycia jest istotna ze względu na jego podobieństwo morfologiczne do innych, znacznie bardziej szkodliwych i powszechnie występujących na terenie Polski gatunków wciornastków, m.in. T. tabaci.

Opracowania literaturowe dotyczące tego gatunku są również bardzo nieliczne. Ostatnio opisano charakterystykę sekwencji oraz analizy filogenetyczne regionów kodujących geny $18 \mathrm{~S}$ rDNA, 28S rDNA, podjednostki pierwszej oksydazy cytochromowej mtDNA (COI), tubuliny- $\alpha$ I i histonu 3 dla 99 gatunków wciornastków, należących do 7 różnych rodzin, m.in. dla $F$. occidentalis, jednakże w tym zestawieniu zabrakło T. major (Buckman i wsp. 2013). Opublikowano również dane podające opis fragmentu sekwencji $m t C O I$ dla istotnych gospodarczo gatunków wciornastków oraz możliwość wykorzystania go do diagnostyki, jednak i w tym opracowaniu nie uwzględniono wciornastka cyklamenowca (Brunner i wsp. 2002). Przeprowadzone przez autorów powyższych badań analizy filogenetyczne w obu przypadkach wykazały znaczny dystans genetyczny pomiędzy poszczególnymi przedstawicielami podrodziny Thripinae, co znajduje potwierdzenie także w wynikach przeprowadzonych badań własnych.

$\mathrm{Na}$ podstawie analizy sekwencji rDNA powszechnie występujących w Polsce gatunków wciornastków wykazano znaczne różnice $\mathrm{W}$ tym regionie, co stwarza możliwość wykorzystania go do opracowania protokołów do identyfikacji gatunkowej. Konieczne jest jednak przeanalizowanie większej liczby populacji wciornastka T. major oraz uwzględnienie w badaniach większej liczby gatunków, aby metoda mogła być wiarygodna. 


\begin{tabular}{|c|c|c|c|c|c|c|c|c|}
\hline Seq-> & F.occi. & F.intonsa & F.schulzei & S.dorsalis & E. americanus & T.palmi & T.tabaci & T.major \\
\hline F. occi. & ID & 0,692 & 0,318 & 0,300 & 0,326 & 0,332 & 0,290 & 0,266 \\
\hline F. intonsa & 0,692 & ID & 0,301 & 0,296 & 0,305 & 0,312 & 0,286 & 0,255 \\
\hline F. schulzei & 0,318 & 0,301 & ID & 0,271 & 0,371 & 0,309 & 0,274 & 0,215 \\
\hline S. dorsalis & 0,300 & 0,296 & 0,271 & ID & 0,290 & 0,276 & 0,299 & 0,298 \\
\hline E. americanus & 0,326 & 0,305 & 0,371 & 0,290 & ID & 0,325 & 0,291 & 0,234 \\
\hline T. palmi & 0,332 & 0,312 & 0,309 & 0,276 & 0,325 & ID & 0,316 & 0,251 \\
\hline T. tabaci & 0,290 & 0,286 & 0,274 & 0,299 & 0,291 & 0,316 & ID & 0,257 \\
\hline major & 0,266 & 0,255 & 0,215 & 0,298 & 0,234 & 0,251 & 0,257 & ID \\
\hline
\end{tabular}

Rys. 2. Poziom identyczności pomiędzy gatunkiem T. major a gatunkami T. tabaci, T. palmi, S. dorsalis, E. americanus, F. schulzei, $F$. occidentalis i $F$. intonsa. Uzyskano w programie BioEdit

Fig. 2. Identity between T. major and species: T. tabaci, T. palmi, S. dorsalis, E. americanus, F. schulzei, F. occidentalis and F. intonsa. Results obtained in BioEdit software

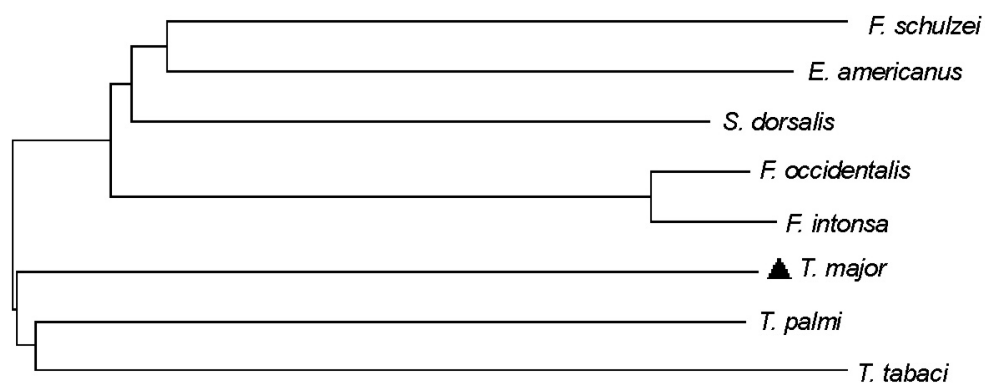

0.1

Rys. 3. Wyniki analizy filogenetycznej pomiędzy gatunkami: T. major, T. tabaci, T. palmi, S. dorsalis, E. americanus, F. schulzei, F. occidentalis, F. intonsa. Analiza została wykonana przy pomocy programu MEGA4. Poniżej zaznaczono dystans genetyczny

Fig. 3. Results of phylogenetic analysis between species: T. major, T. tabaci, T. palmi, S. dorsalis, E. americanus, F. schulzei, $F$. occidentalis, $F$. intonsa. Analysis was performed in MEGA4 software. Genetic distance is provided below diagram

\section{Wnioski / Conclusions}

1. Poznano sekwencję T. major o długości około 1900 pz, wykazującą niewielkie, bo zaledwie $22-30 \%$ podobieństwo oraz duży dystans filogenetyczny pomiędzy najbliżej spokrewnionymi gatunkami wciornastków.

2. Poznanie sekwencji T. major fragmentu 18S-ITS15,8S-ITS2-28S rDNA oraz duże zróżnicowanie pomię- dzy poszczególnymi gatunkami wciornastków w powyższym regionie stwarza możliwość wykorzystania tej sekwencji podczas dalszych prac nad opracowaniem szybkich metod diagnostycznych, opartych np. na reakcji PCR lub real-time PCR. Konieczne sa jednak dodatkowe analizy obejmujące więcej populacji T. major oraz większą liczbę gatunków wciornastków.

\section{Literatura / References}

Brunner P.C., Flemming C., Frey J.E. 2002. A molecular identification key for economically important thrips species (Thysanoptera: Thripidae) using direct sequencing and a PCR-RFLP-based approach. Agric. For. Entomol. 4: 127-136.

Buckman R.S., Mound L.A., Whiting M.F. 2013. Phylogeny of thrips (Insecta: Thysanoptera) based on five molecular loci. System. Entomol. 38: 123-133.

Liu Y.C. 2004. Molecular identification of a plant quarantine pest (Frankliniella occidentalis) by one-tube nested PCR targeting ribosomal DNA internal transcribed spacer regions. Zhi Wu Bao Hu Xue Hui Hui Kan 46: 27-46.

Nicholas K.B., Nicholas H.B. 1997. GeneDoc, a tool for editing and annotating multiply sequence alignments. Pittsburgh Supercomputing Center's National Resource for Biomedical Supercomputing. http://www.nrbsc.org/downloads/. Accessed: 02.03.2007.

Pobożniak M. 2005. Thrips species on white cabbage. Electronic J. Polish Agric. Univ. Hortic. 8 (4), p. 60.

Pobożniak M., Sobolewska A. 2011. Biodiversity of thrips species (Thysanoptera) of flowering herbs in Cracow, Poland. J. Plant Prot. Res. 51 (4): 393-398.

Stacey D.A., Fellowes M.D.E. 2002. Temperature and development rates of thrips. Evidence for a constraint on local adaptation? Eur. J. Entomol. 99: 399-404.

Tamura K., Dudley J., Nei M., Kumar S. 2007. MEGA4: Molecular Evolutionary Genetics Analysis (MEGA) software version 4.0. Mol. Biol. Evol. 24: 1596-1599.

Thompson D., Higgins D.G., Gibson T.J. 1994. CLUSTALW: improving the sensitivity of progressive multiple sequence alignment through sequence weighting, position-specific gap penalties and weight matrix choice. Nucleic Acids Res. 22: 4673-4680.

Zawirska I. 1994. Wciornastki - Thysanoptera. s. 145-175. W: „Diagnostyka szkodników roślin i ich wrogów naturalnych”. SGGW, Warszawa, 328 ss. 